\author{
MAŁGORZATA MĘDRALA \\ ORCID: 0000-0002-0068-2975 \\ Uniwersytet Ekonomiczny w Krakowie
}

\title{
ZASADA SZYBKOŚCI POSTĘPOWANIA W SPRAWACH Z ZAKRESU PRAWA PRACY PO NOWELIZACJI K.P.C.
}

\begin{abstract}
Abstrakt: Przedmiotem artykułu jest analiza najważniejszych regulacji postępowania cywilnego w sprawach z zakresu prawa pracy wprowadzonych na mocy nowelizacji w 2019 roku w kontekście formułowanej w doktrynie zasady szybkości tego postępowania.

Autorka omawia źródła wskazanej zasady w prawie międzynarodowym oraz krajowym. Z perspektywy tej zasady analizie poddaje ogólny nowy model postępowania cywilnego oraz, kolejno, najważniejsze zmiany w postępowaniu odrębnym w sprawach z zakresu prawa pracy.
\end{abstract}

Słowa kluczowe: procedura cywilna, sprawy z zakresu prawa pracy, zasada szybkości postępowania, pracownik, powód

\section{WPROWADZENIE}

Ustawa z 4 lipca 2019 roku o zmianie ustawy — Kodeks postępowania cywilnego oraz niektórych innych ustaw ${ }^{1}$ wprowadziła $z$ dniem 7 listopada 2019 roku ważne zmiany modelowe $\mathrm{w}$ polskiej procedurze cywilnej. Zmiany te $\mathrm{w}$ istotny sposób dotknęły zarówno ogólne zasady postępowania w sprawach cywilnych, jak i samo postępowanie odrębne w sprawach z zakresu prawa pracy. Jednym z zakładanych celów zmian miało być usprawnienie i przyśpieszenie postępowania w sprawach cywilnych. Odbywać się to miało przede wszystkim przez planowanie $\mathrm{z}$ góry podejmowanych czynności $\mathrm{w}$ toku procesu, w szczególności w ramach posiedzeń przygotowawczych oraz sporządzanych planów rozpraw. Celem niniejszego artykułu jest krytyczna analiza przyjętych rozwiązań w kontekście zasady szybkości w sprawach z zakresu prawa pracy. Dla porządku należy przy tym dodać, iż w nauce prawa pracy mówi się zazwyczaj o zasadzie szybkości postępo-

\footnotetext{
1 Dz.U. z 2019 r. poz. 1469.
} 
wania w sprawach z zakresu prawa pracy ${ }^{2}$. W doktrynie postępowania cywilnego częściej używa się jednak określenia „,postulat” szybkości postępowania ${ }^{3}$.

Ze względu na objętość niniejszego tekstu w ramach poniższych rozważań skoncentruję się jedynie na wybranych nowych regulacjach specyficznych odnośnie do postępowania odrębnego w sprawach pracowniczych.

\section{PRAWNE GWARANCJE ZASADY SZYBKOŚCI POSTĘPOWANIA}

Należy wskazać, że szybkość postępowania jest jedną z podstawowych gwarancji sprawnego i rzetelnego procesu we wszystkich sprawach cywilnych, w sprawach zaś z zakresu prawa pracy jej znaczenie jest szczególnie doniosłe. Dotyczy to zwłaszcza spraw związanych $\mathrm{z}$ wynagrodzeniami pracowników oraz bytem stosunku pracy. $\mathrm{W}$ tym zakresie postępowanie w sprawach z zakresu prawa pracy pełni nie tylko tradycyjną funkcję ochronną, ale także funkcję socjalną związaną z zapewnieniem podstawowych środków utrzymania dla pracownika i jego rodziny. Ze względu przy tym na alimentarną funkcję wynagrodzenia za pracę w praktyce dla pracownika jako strony z założenia słabszej ekonomicznie przewlekanie postępowania jest sytuacją o wiele trudniejszą niż dla pracodawcy ${ }^{4}$. Społeczna waga wymienionych problemów leży u podłoża konstruowania postulatu/zasady szybkości postępowania w sprawach z zakresu prawa pracy.

$\mathrm{Na}$ treść zasady prawa do sądu składa się, oprócz samego prawa dostępu do sądu i wyroku sądowego, także prawo do odpowiedniego ukształtowania procedury sądowej, zgodnie z wymogami sprawiedliwości i jawności ${ }^{5}$. Odpowiednie ukształtowanie procedury oznacza między innymi prawo do rozpatrzenia sprawy w rozsądnym terminie. Pojęcie rozsądnego terminu powinno przy tym być rozpatrywane z uwzględnieniem specyfiki spraw danego rodzaju.

Artykuł 47 zd. 2 Karty Praw Podstawowych Unii Europejskiej traktuje o prawie każdego do sprawiedliwego i jawnego rozpatrzenia sprawy w rozsądnym terminie. W orzecznictwie unijnym wskazuje się przy tym, iż „rozsądny charakter terminu powinien być oceniany w zależności od właściwych dla każdej sprawy okoliczności, a w szczególności znaczenia sporu dla zainteresowanego, złożono-

2 T. Liszcz, K. Ślebzak oraz K.W. Baran piszą o zasadzie szybkości postępowania — zob. K. Ślebzak, [w:] Prawo pracy, red. Z. Niedbała, Warszawa 2012, s. 344; T. Liszcz, Prawo pracy, Warszawa 2014, s. 489; K.W. Baran, [w:] Prawo pracy i ubezpieczeń społecznych, red. K.W. Baran, Warszawa 2019, s. 690.

3 Por. M. Mędrala, Funkcja ochronna cywilnego postępowania sądowego w sprawach z zakresu prawa pracy, Warszawa 2011, s. 180; A. Góra-Błaszczykowska używa określenia „zasada” szybkości - A. Góra-Błaszczykowska, [w:] System Prawa Pracy, t. 6. Procesowe prawo pracy, Warszawa 2016, s. 410-411.

${ }^{4}$ Zob. M. Mędrala, op. cit., s. 180.

5 Por. wyrok TK z 11 czerwca 2002 roku, SK 5/02, OTK-A 2002, nr 4, poz. 41; M. Mędrala, op. cit., s. 48 . 
ści sprawy oraz zachowania strony skarżącej i właściwych władz"6. O rozsądnym terminie rozpatrzenia sprawy stanowi także artykuł 6 ust. 1 Konwencji o ochronie praw człowieka i podstawowych wolności z 4 listopada 1950 roku? .

Prawo do sprawiedliwego i jawnego rozpatrzenia sprawy bez nieuzasadnionej zwłoki przez właściwy, niezależny, bezstronny i niezawisły sąd jest gwarantowane na gruncie art. 45 ust. 1 Konstytucji. Wskazuje się, iż „szybkie uzyskanie rozstrzygnięcia sądowego leży nie tylko w bezpośrednim interesie jednostki, ale także w interesie publicznym" zobowiązań międzynarodowych rozsądne terminy załatwienia spraw podkreśla się przy rozstrzyganiu spraw sądowych „uznanych w wewnętrznym porządku prawnym za wymagające szczególnych procedur zapewniających sprawność i szybkość postępowań sądowych, do których zaliczają się sprawy z zakresu prawa pracy oraz ubezpieczeń społecznych, gdyż polegają one często na osądzaniu kwestii o życiowym znaczeniu dla zapewnienia bytu materialnego pracownikom lub ubezpieczonym”9. Sprawy z zakresu prawa pracy traktowane są jako „istotne z punktu widzenia szczególnej potrzeby społecznej zagwarantowania wzmożonej sprawności i szybkości ich osądzania"10.

Oprócz ogólnej zasady sprawnego prowadzenia postępowania w sprawach cywilnych z art. 6 k.p.c. ${ }^{11}$ postulat/zasada szybkości postępowania jest także formułowany osobno odnośnie do postępowania odrębnego w sprawach pracowniczych $^{12}$. Prawo do sądu w sprawach pracowniczych sformułowane zostało dodatkowo w kodeksie pracy (art. 242 k.p.). Jego wyrazem jest wprowadzenie specjalnego trybu postępowania odrębnego dla tej kategorii spraw, połączonego z gwarancjami o charakterze ustrojowo-organizacyjnym w postaci odrębnych wydziałów pracy w ramach sądownictwa powszechnego ${ }^{13}$.

Wśród charakterystycznych instytucji mających na celu realizację zasady szybkości postępowania w sprawach z zakresu prawa pracy, które zostały utrzymane $\mathrm{w}$ dotychczasowym stanie prawnym, wskazać należy:

${ }^{6}$ N. Półtorak, A. Wróbel, komentarz do artykułu 47 Karty Praw Podstawowych, pkt E.1, [w:] Karta Praw Podstawowych Unii Europejskiej. Komentarz, red. A. Wróbel, Warszawa 2020, oraz cytowane tam wyroki TS.

7 Dz.U. z 1993 r. Nr 61, poz. 284.

8 P. Grzegorczyk, K. Weitz, komentarz do art. 45 Konstytucji RP, teza VII.13, [w:] Konstytucja RP, t. 1. Komentarz do art. 1-86, red. M. Safjan, L. Bosek, Warszawa 2016.

9 Postanowienie SN z 8 marca 2005 roku, III SPP 34/05, OSNP 2005, nr 20, poz. 327.

10 Ibidem.

11 Zgodnie z tym przepisem sąd powinien przeciwdziałać przewlekaniu postępowania i dążyć do tego, aby rozstrzygnięcie nastąpiło na pierwszym posiedzeniu, jeżeli jest to możliwe bez szkody dla wyjaśnienia sprawy.

Strony i uczestnicy postępowania obowiązani są przytaczać wszystkie fakty i dowody bez zwłoki, aby postępowanie mogło być przeprowadzone sprawnie i szybko.

12 Szerzej M. Mędrala, op. cit., s. 180-183 i przywołana tam literatura.

13 Ibidem, s. 111-135. 
— udogodnienia procesowe w postaci: przemiennej właściwości sądów pracy (art. $461 \S 1$ k.p.c. ${ }^{14}$ ), możliwości wytaczania powództw oraz przystępowania do spraw przez organizacje pozarządowe w zakresie swoich zadań statutowych (art. 462 k.p.c.), rozszerzonego kręgu podmiotów mogących być pełnomocnikiem pracownika (art. $465 \S 1$ k.p.c.), wzywania świadków, stron oraz żądania przedstawienia dokumentów w trybie art. $149^{1}$ k.p.c. (art. 472 k.p.c.), możliwości zgłaszania przez pracownika niedziałającego przez profesjonalnego pełnomocnika powództwa, środków odwoławczych, pism procesowych oraz poprawek i uzupełnień do nich ustnie do protokołu (art. 466 k.p.c.);

— zwiększoną działalność sądu z urzędu, której wyrazem jest art. 464 § 1 k.p.c. ${ }^{15}$, brak ograniczeń dopuszczalności dowodu z zeznań świadków i przesłuchania stron (art. 473 k.p.c.), możliwość wezwań z urzędu w trybie art. 194 § 1 i 3 k.p.c. (art. 477 zd. 1 k.p.c.), pouczenie przez sąd pracownika o roszczeniach wynikających z przytoczonych przez niego faktów (art. 477 zd. 2 k.p.c.) czy nadawanie z urzędu klauzuli wykonalności wyrokowi zasądzającemu należność na rzecz pracownika (art. $477^{2}$ k.p.c.).

Jednocześnie ustawodawca dokonał w ramach nowelizacji wielu zmian przepisów na poziomie zwykłego procesu cywilnego oraz wprowadził zmiany w samym postępowaniu odrębnym.

\section{ZASADA SZYBKOŚCI POSTĘPOWANIA A NOWY MODEL PROCESU CYWILNEGO}

Wśród najważniejszych zmian, służących przyśpieszeniu postępowania w ogólnych przepisach o procesie cywilnym wymienia się z jednej strony nową organizację postępowania (art. $205^{1}$ n. k.p.c.), związaną z dążeniem do załatwienia sprawy w postępowaniu przygotowawczym bez wyznaczania rozprawy, a gdyby konieczne było wyznaczenie rozprawy - z opracowaniem jej planu przez sąd $\mathrm{z}$ udziałem stron. $Z$ drugiej strony wymienia się przepisy mające na celu przeciwdziałanie nadużyciom prawa procesowego, a w szczególności regulacje dotyczące łańcucha zażaleń (art. $394^{3}$ k.p.c.) oraz wniosków o: wyłączenie sędziego (art. $53^{1}$ k.p.c.), sprostowanie, uzupełnienie i wykładnię wyroku (art. $350^{1}$ k.p.c.), a także o ustanowienie pełnomocnika z urzędu (art. $117^{2} \S 2$ k.p.c. $)^{16}$.

14 „Powództwo w sprawie z zakresu prawa pracy można wytoczyć bądź przed sąd ogólnie właściwy dla pozwanego, bądź przed sąd, w którego obszarze właściwości praca jest, była lub miała być wykonywana".

15 „Odrzucenie pozwu nie może nastąpić z powodu niedopuszczalności drogi sądowej, gdy do rozpoznania sprawy właściwy jest inny organ. W tym przypadku sąd przekaże sprawę temu organowi. Jeżeli jednak organ ten uprzednio uznał się za niewłaściwy, sąd rozpozna sprawę".

${ }^{16}$ R. Flejszar, Postępowania przyspieszone po zmianach wprowadzonych nowelizacja KPC z 4.7.2019 r., „Monitor Prawniczy” 2019, nr 21, s. 1176. 
O ile druga grupa regulacji zasługuje moim zdaniem jak najbardziej na pozytywną ocenę w kontekście wszystkich spraw cywilnych, w tym z zakresu prawa pracy, o tyle dużo większe kontrowersje budzić może pierwsza grupa przepisów związana z nową organizacją postępowania. W tym ujęciu wśród procesualistów wyrażane są krytyczne uwagi na temat braku obecnie w postępowaniu cywilnym jednolitego systemu koncentracji materiału procesowego. Wskazuje się, iż dokonane zmiany $\mathrm{w}$ istocie pozbawiły pozew i odpowiedź na pozew znaczenia z punktu widzenia koncentracji materiału procesowego (utraty prawa do powoływania $\mathrm{w}$ toku dalszego postępowania nowych twierdzeń i dowodów $)^{17}$. Z jednej strony niewątpliwie za pozytywne dla organizacji postępowania należy uznać wprowadzenie obowiązku złożenia obligatoryjnej odpowiedzi na pozew (art. $205^{1}$ k.p.c.) ${ }^{18}$, co może usprawnić przebieg postępowania. $Z$ drugiej strony jednak w literaturze słusznie zwrócono uwagę, iż zarządzeniu zobowiązującemu pozwanego do złożenia odpowiedzi na pozew $\mathrm{w}$ określonym terminie nie towarzyszy rygor pominięcia twierdzeń i dowodów, które w odpowiedzi na pozew nie zostaną zgłoszone ${ }^{19}$. Dlatego też wydaje się, iż w celu osiągnięcia efektu koncentracji materiału dowodowego i urealnienia znaczenia odpowiedzi na pozew z punktu widzenia sprawnej organizacji postępowania, sąd powinien wykorzystywać instytucję z art. $205^{3} \S 2$ k.p.c., zgodnie z którym przewodniczący może zobowiązać stronę, by w piśmie przygotowawczym podała wszystkie twierdzenia i dowody istotne dla rozstrzygnięcia sprawy pod rygorem utraty prawa do ich powoływania $w$ toku dalszego postępowania. $\mathrm{W}$ takim przypadku twierdzenia i dowody zgłoszone $\mathrm{z}$ naruszeniem tego obowiązku podlegają pominięciu, chyba że strona uprawdopodobni, iż ich powołanie w piśmie przygotowawczym nie było możliwe albo że potrzeba ich powołania wynikła później.

Wyrażam pogląd, że w sprawach z zakresu prawa pracy regułą powinno być wyznaczanie posiedzenia przygotowawczego. Uzasadnia to zarówno charakter i waga społeczna spraw pracowniczych, jak i funkcja samego posiedzenia. Jedynie w sprawach prostych i niebudzących wątpliwości pod kątem wyjaśnienia dodatkowych kwestii formalnych, posiedzenie przygotowawcze nie będzie miało sensu. Z jednej bowiem strony, zgodnie z art. $205^{4} \S 3$ k.p.c., jeżeli okoliczności sprawy wskazują, że przeprowadzenie posiedzenia przygotowawczego nie przyczyni się do sprawniejszego rozpoznania sprawy, przewodniczący może jej nadać inny właściwy bieg, a w szczególności skierować ją do rozpoznania, także na rozprawie. $\mathrm{Z}$ drugiej strony $\mathrm{w}$ obecnym stanie prawnym dostrzec można jednak pewne motywy, którymi kierują się sądy, decydując się na nieprzeprowadzanie po-

17 Zob. M. Sieńko, Nowe modele koncentracji materiatu procesowego, [w:] Reforma czy kolejna nowelizacja? Uwagi na tle ustawy z 4.7.2019 r. zmieniajacej KPC, red. P. Rylski, Warszawa 2020, s. 20.

18 J. May, Proceedings in matters of labour law after the amendment to the Polish Code of Civil Procedure, „Praca i Zabezpieczenie Społeczne” 2020, nr 3, s. 41.

19 Zob. M. Sieńko, op. cit., s. 26. 
siedzeń przygotowawczych. Dzięki temu możliwe jest bowiem uniknięcie przez sądy konieczności sporządzania planów rozpraw, których zmiana ma charakter dość sformalizowany i czasochłonny ${ }^{20}$. Ponadto w sprawach, w których nie zarządzono przeprowadzenia posiedzenia przygotowawczego, strona może przytaczać twierdzenia i dowody na uzasadnienie swoich wniosków lub dla odparcia wniosków i twierdzeń strony przeciwnej aż do zamknięcia rozprawy, z zastrzeżeniem niekorzystnych skutków, które według przepisów kodeksu mogą dla niej wyniknąć z działania na zwłokę lub niezastosowania się do zarządzeń przewodniczącego i postanowień sądu (art. $205^{12} \S 2$ k.p.c.).

Mieszane odczucia w sprawach z zakresu prawa pracy mogą także wywoływać zarówno regulacje procesowe, zmierzające do rozwiązywania jak największej liczby spraw na drodze ugodowej, jak i zwiększone obowiązki sądu w zakresie pouczania stron procesowych. Niewątpliwie istotne znaczenie będzie miał nowy art. $156^{1}$ k.p.c., zgodnie z którym, w miarę potrzeby, na posiedzeniu przewodniczący może pouczyć strony o prawdopodobnym wyniku sprawy w świetle zgłoszonych do tej chwili twierdzeń i dowodów. Jak wskazuje J. May, może to prowadzić do wywierania nacisku przez sąd na strony niereprezentowane przez fachowego pełnomocnika do zawierania ugód ${ }^{21}$, tym bardziej iż forma ugodowego rozwiązania sporu jest także preferowana na gruncie art. $205^{6} \S 2$ k.p.c., zgodnie z którym przewodniczący powinien skłaniać strony do pojednania oraz dążyć do ugodowego rozwiązania sporu, w szczególności w drodze mediacji. W tym celu przewodniczący może poszukiwać ze stronami ugodowych sposobów rozwiązania sporu, wspierać je w formułowaniu propozycji ugodowych oraz wskazywać sposoby i skutki rozwiązania sporu, w tym skutki finansowe. Praktyka jednak pokazuje, że ze względu na $\mathrm{z}$ reguły słabszą ekonomicznie w procesie pozycję pracownika częściej będzie on skłonny taką ugodę zawrzeć. Podobny efekt może także wywoływać regulacja art. $156^{2}$ k.p.c., zgodnie z którą jeżeli w toku posiedzenia okaże się, że o żądaniu lub wniosku strony można rozstrzygnąć na innej podstawie prawnej niż przez nią wskazana, uprzedza się o tym strony obecne na posiedzeniu. Z jednej strony regulacje te mogą więc przyspieszyć postępowanie, przez wyeliminowanie na wczesnym etapie spraw niezasadnych lub w przypadku których zawarcie ugody stanowi uniknięcie niepotrzebnych kosztów i czasu. Z drugiej jednak strony mogą także w praktyce sądowej być formą nacisku na ugodowe załatwianie spraw.

20 Zob. art. $205^{11}$ k.p.c. Por. także M. Dziurda, Posiedzenie przygotowawcze i plan rozprawy, [w:] Reforma czy kolejna nowelizacja? Uwagi na tle ustawy z 4.7.2019 r. zmieniajacej KPC, red. P. Rylski, Warszawa 2020, s. 87; oraz A. Mendrek, Reforma prawa dowodowego w świetle ustawy z 4.07.2019 r. o zmianie ustawy - Kodeks postepowania cywilnego oraz niektórych innych ustaw, [w:] Nowelizacja Kodeksu postępowania cywilnego z 4.07.2019 r. w praktyce, red. K. Flaga-Gieruszyńska, R. Flejszar, M. Malczyk, Warszawa 2020, s. 102-103.

21 J. May, op. cit., s. 43. 


\section{ZNIESIENIE CZYNNOŚCI WYJAŚNIAJĄCYCH ORAZ WSTĘPNEGO BADANIA SPRAWY}

Najważniejszą ze zmian w samym postępowaniu odrębnym w sprawach z zakresu prawa pracy jest zniesienie instytucji czynności wyjaśniających oraz konieczności wstępnego badania sprawy przez przewodniczącego. Funkcjonujące $\mathrm{w}$ dotychczasowym kształcie wskazane instytucje z założenia miały na celu przyspieszenie postępowania ${ }^{22}$. Służyły one usuwaniu braków formalnych uniemożliwiających dalszy bieg postępowania, nakłanianiu do ugodowego załatwienia sprawy, wyjaśnieniu stanowisk stron, ustaleniu spornych okoliczności oraz koniecznych dowodów ${ }^{23}$.

Jako przyczynę takiej zmiany w uzasadnieniu do projektu ustawy ${ }^{24}$ wskazuje się, iż „zmiany w przepisach regulujących postępowanie w sprawach z zakresu prawa pracy są konsekwencją wprowadzenia postępowania przygotowawczego w procesie cywilnym. Będące jego jądrem posiedzenie przygotowawcze ma te same cele i wyniki, co dotychczasowe instytucje wstępnego badania sprawy i czynności wyjaśniających, a przy tym jeszcze umożliwia organizację rozprawy". Ponadto, cele posiedzenia przygotowawczego w sprawach pracowniczych i ubezpieczeniowych zostały poszerzone w porównaniu do jego celów w „zwykłym” procesie (art. $467 \S 3^{1}-3^{2}$ k.p.c.), przez co uwzględniają specyfikę spraw z zakresu prawa pracy polegającą na łagodniejszym podejściu do braków formalnych i merytorycznych pozwu czy mniej restrykcyjnym podejściu do dopuszczania dowodów $z$ urzędu ${ }^{25}$.

W znowelizowanych przepisach kodeksu postępowania cywilnego art. 468 k.p.c., dotyczący czynności wyjaśniających, został w całości uchylony, a w art. 467 k.p.c. skreślone zostały przepisy, regulujące wstępne badanie sprawy. Praktyka pokazywała przy tym, iż czynności w zakresie wstępnego badania sprawy miały znaczenie w szczególności w sprawach ubezpieczeniowych, pozwalając na zwrot organowi rentowemu akt $\mathrm{w}$ celu uzupełnienia materiału dowodowego. Natomiast nowo dodany $\S 3^{1}$ art. 467 k.p.c. stanowi, iż stronę wnoszącą pismo wszczynające postępowanie wzywa się do usunięcia jego braków, tylko gdy braki te uniemożliwiają przeprowadzenie posiedzenia przygotowawczego z udziałem strony wnoszącej pismo. Rozwiązanie to ma więc na celu ekonomikę postępowania w sprawach z zakresu prawa pracy. Zasadą ma być uzupełnianie braków formalnych $\mathrm{w}$ toku postępowania przygotowawczego. Potwierdza to także dodany kolejno $\S 3^{2}$ art. 467 k.p.c., według którego posiedzenie przygotowawcze służy także usunięciu braków pisma

22 Zob. Z. Świeboda, [w:] W. Siedlecki, Z. Świeboda, Postępowanie cywilne. Zarys wyktadu, Warszawa 2004, s. 344-345.

23 Por. art. 467-468 k.p.c. w brzmieniu sprzed nowelizacji.

24 Uzasadnienie rządowego projektu ustawy o zmianie ustawy - Kodeks postępowania cywilnego oraz niektórych innych ustaw, druk nr 3137 Sejmu VIII kadencji, s. 113.

25 Ibidem. 
wszczynającego postępowanie w zakresie niezbędnym do nadania sprawie prawidłowego biegu oraz, w razie potrzeby, ustaleniu przez sąd dowodów do przeprowadzenia z urzędu, a także wyjaśnieniu innych okoliczności istotnych dla prawidłowego i szybkiego rozpoznania sprawy. W doktrynie wskazuje się, iż dotyczy to okoliczności niewymagających przeprowadzenia postępowania dowodowego w ramach rozprawy, w szczególności objętych notoryjnością (art. 228 k.p.c.), przyznaniem (art. 229-230 k.p.c.), a także okoliczności, wynikających z dokumentów przedstawionych przez jedną ze stron i niezakwestionowanych przez stronę przeciwną ${ }^{26}$. Posiedzenie przygotowawcze ma także pozwolić na sprecyzowanie oznaczenia strony pozwanej — tak aby było możliwe doręczenie jej odpisu pozwu ${ }^{27}$.

Można powiedzieć więc, że de facto posiedzenie przygotowawcze oraz dodane do art. 467 k.p.c. paragrafy $3^{1}-3^{2}$ k.p.c. zastąpiły dotychczasowe wstępne badanie sprawy oraz czynności wyjaśniające.

Na marginesie dodać należy, iż art. $467 \S 3^{1}$ k.p.c. nie ma zastosowania w sprawach z zakresu prawa pracy, w których pracownik jest stroną pozwaną (art. $477^{7}$ k.p.c.) oraz do skargi kasacyjnej i postępowania przed Sądem Najwyższym wywołanego jej wniesieniem (art. $475^{1}$ k.p.c.), co należy ocenić jako rozwiązania zasadne. Pierwsze z wyłączeń stanowi także wyraz preferowania przez ustawodawcę funkcji ochronnej procesowych przepisów prawa pracy w sprawach, w których pracownik występuje jako strona powodowa.

W tym kontekście w doktrynie można spotkać jednak głosy krytyczne na temat nowego rozwiązania. Czynności wyjaśniające uznaje się za zdecydowanie spójniejsze i elastyczniejsze ${ }^{28}$. Zgodnie z poprzednio obowiązującym (w bardziej stanowczym brzmieniu) art. $468 \S 1$ k.p.c. sąd ,podejmie” czynności wyjaśniające, jeżeli przemawiają za tym wyniki wstępnego badania sprawy, chyba że czynności te nie przyśpieszą postępowania lub są oczywiście niecelowe z innych przyczyn. Czynności te miały charakter względnie obligatoryjny ${ }^{29}$.

Na podkreślenie zasługuje moim zdaniem w szczególności to, iż czynności wyjaśniające służyły ustaleniu okoliczności spornych między stronami, istotnych dla rozstrzygnięcia sprawy, a także ustaleniu, czy i jakie dowody należy przeprowadzić w celu ich wyjaśnienia (uchyl. art. 468 § 2 pkt 3 i 4 k.p.c.). Tym samym czynności wyjaśniające pozwalały na dalsze szybsze procedowanie sprawy. Tymczasem w świetle znowelizowanych regulacji z jednej strony art. $205^{4} \S 1$ k.p.c. ${ }^{30}$

${ }^{26}$ M. Muliński, komentarz do art. 467 k.p.c., teza 7, [w:] Kodeks postępowania cywilnego. Komentarz, t. 1. Art. 425-729, red. A. Góra-Błaszczykowska, Warszawa 2020.

27 M. Dziurda, op. cit., s. 46.

28 Ibidem, s. 45.

${ }^{29}$ K. Flaga-Gieruszyńska, Czynności wyjaśniające, [w:] System Prawa Pracy, t. 6. Procesowe prawo pracy, red. K.W. Baran, Warszawa 2016, s. 591.

30 „Po złożeniu odpowiedzi na pozew, a także gdy odpowiedź na pozew nie została złożona, ale wyrok zaoczny nie został wydany, przewodniczący wyznacza posiedzenie przygotowawcze i wzywa na nie strony". 
został zredagowany tak, jakby posiedzenie przygotowawcze było obligatoryjne, z drugiej zaś strony zgodnie z art. $205^{4} \S 3$ k.p.c. w każdej sprawie przewodniczący może od jego wyznaczania odstąpić31 (gdy „okoliczności sprawy wskazują, że przeprowadzenie posiedzenia przygotowawczego nie przyczyni się do sprawniejszego rozpoznania sprawy"). Uzasadnione jest zatem twierdzenie, iż obecne regulacje czynią $\mathrm{w}$ większym stopniu posiedzenia przygotowawcze w sprawach z zakresu prawa pracy instytucjami fakultatywnymi, niż takimi były ich odpowiedniki w postępowaniach na gruncie poprzednio obowiązujących przepisów. Za niechęcią sądów do ich przeprowadzania może także przemawiać wspomniana już wcześniej skomplikowana procedura opracowywania i zmiany planów rozpraw. $\mathrm{W}$ moim przekonaniu regułą $\mathrm{w}$ sprawach pracowniczych powinno być wyznaczenie posiedzeń przygotowawczych, które zastąpiły poprzednie instytucje. Dotychczasowa, stosunkowo krótka, praktyka pokazuje jednak zróżnicowane podejście sądów do tej instytucji w różnych apelacjach.

\section{TERMIN ROZPRAWY}

Na mocy nowelizacji zmiani się także art. 471 k.p.c. Zgodnie z dotychczasowym brzmieniem tego przepisu termin rozprawy powinien być wyznaczony tak, aby od daty zakończenia czynności wyjaśniających, a jeżeli nie podjęto tych czynności - od daty wniesienia pozwu lub odwołania, do rozprawy nie upłynęło więcej niż dwa tygodnie, chyba że zachodzą niedające się usunąć przeszkody. Termin ten miał charakter instrukcyjny ${ }^{32}$. Praktyka stosowania znowelizowanego przepisu pokazywała jednak, iż wskazany przez ustawodawcę termin nie był respektowany.

W powyższym kontekście uzasadnienie zmiany w tym zakresie w projekcie ustawy nowelizującej k.p.c. należy uznać z jednej strony za rozczarowujące, a z drugiej — za realistyczne. Jak wskazuje się bowiem w uzasadnieniu:

Termin do rozpoznania sprawy z zakresu prawa pracy powinien zostać zachowany, należy jednak zmienić jego charakter tak, by uwzględniał realia obecnego nadmiernego obciążenia sądów powszechnych - nie poprzez nałożenie na sąd obowiązku przeprowadzenia posiedzenia, lecz poprzez zobowiązanie sądu i przewodniczącego do odpowiedniego podejmowania czynności w tym celu ${ }^{33}$.

Dlatego też przepis art. 471 k.p.c. w brzmieniu obowiązującym od 7 listopada 2019 roku stanowi, iż przewodniczący i sąd są obowiązani podejmować czynności tak, by termin posiedzenia, na którym sprawa ma zostać rozpoznana, przypadł nie

31 M. Dziurda, op. cit., s. 45.

32 K. Gonera, komentarz do art. 471 k.p.c., teza 2, [w:] Kodeks posteppowania cywilnego, t. 3. Komentarz. Art. 425-729, red. A. Marciniak, Warszawa 2020.

33 Uzasadnienie rządowego projektu..., s. 113. 
później niż miesiąc od dnia zakończenia posiedzenia przygotowawczego, a jeżeli go nie przeprowadzono - nie później niż sześć miesięcy od dnia złożenia odpowiedzi na pozew. Jeżeli odpowiedź na pozew była obarczona brakami, termin ten biegnie od dnia ich usunięcia, a jeżeli odpowiedzi nie złożono — od dnia upływu terminu do jej złożenia.

Warto w tym miejscu wskazać, iż ogólną zasadą w postępowaniu cywilnym w zakresie wyznaczania posiedzenia przygotowawczego (art. $205^{4}$ k.p.c.) jest to, iż przewodniczący i sąd są obowiązani podejmować czynności tak, by termin pierwszego posiedzenia przygotowawczego przypadł nie później niż dwa miesiące po dniu złożenia odpowiedzi na pozew albo ostatniego pisma przygotowawczego złożonego w wykonaniu zarządzenia przewodniczącego, a jeżeli odpowiedź na pozew albo pismo przygotowawcze nie zostaną złożone — nie później niż dwa miesiące po upływie terminu do złożenia tych pism.

Z powyższego wynika zatem, że w przypadku spraw, w których wyznaczono posiedzenia przygotowawcze, mijać powinny co do zasady trzy miesiące, a spraw, w których posiedzeń przygotowawczych nie było — sześć miesięcy od złożenia odpowiedzi na pozew. Tym samym, biorąc pod uwagę istniejące przesłanki formalistyczne, które mogą powodować niechęć sądów do wyznaczania posiedzeń przygotowawczych, termin sześciu miesięcy wydaje się dość odległy. Co więcej, w obecnym wydaniu przepisów w sposób jednoznaczny przesądzono, iż są to jedynie terminy instrukcyjne. Doliczając do tego czas na złożenie odpowiedzi na pozew czy wstępną wymianę pism procesowych, może to powodować, że w rzeczywistości sprawy z zakresu prawa pracy nie będą rozstrzygane szybciej niż w ciągu roku w ramach pierwszej instancji. Nie będzie to więc z pewnością sprzyjać przyśpieszeniu omawianych postępowań.

Wskazane terminy, podobnie jak w poprzedniej regulacji, powinny być traktowane jako terminy instrukcyjne, które mogą mieć jednak znaczenie przy rozpoznawaniu skarg na przewlekłość, wniesionych na podstawie ustawy z 17 czerwca 2004 roku o skardze na naruszenie prawa strony do rozpoznania sprawy w postępowaniu przygotowawczym prowadzonym lub nadzorowanym przez prokuratora i postępowaniu sądowym bez nieuzasadnionej zwłoki ${ }^{34}$.

Dodać należy, iż artykuł 471 k.p.c. ma zastosowanie obecnie także w postępowaniu uproszczonym (art. $505^{14} \S 1$ k.p.c. $)^{35}$, co z jednej strony w stosunku do poprzedniego stanu prawnego, w którym brakowało takiego odesłania, ocenić należy pozytywnie. Jednak z drugiej strony wydawałoby się, że akurat w tej kategorii spraw pracowniczych (jako z założenia mniej skomplikowanych) termin posiedzenia przygotowawczego powinien być krótszy. Przepis ten nie ma natomiast

34 Dz.U. z 2018 r. poz. 75 ze zm.; K. Gonera, op. cit., teza 3.

35 Zgodnie $\mathrm{z}$ art. $505^{14} \S 1$ k.p.c. w postępowaniu uproszczonym w sprawach z zakresu prawa pracy przepisów art. 466 , art. 477 i art. $477^{1}$ się nie stosuje. Do tej daty przepis ten brzmiał: „W postępowaniu uproszczonym w sprawach z zakresu prawa pracy przepisów art. 466, art. 467, art. 468, art. 470 , art. 471 , art. $477 \mathrm{i}$ art. $477^{1}$ nie stosuje się". 
zastosowania w sprawach, w których pracownik jest stroną pozwaną ${ }^{36}$, w przypadku skargi kasacyjnej i postępowania przed Sądem Najwyższym wywołanego jej wniesieniem ${ }^{37}$, skargi o stwierdzenie niezgodności z prawem prawomocnego orzeczenia ${ }^{38}$.

\section{REPREZENTACJA POZWANEGO}

Kolejna zmiana w przepisach postępowania odrębnego, która ewentualnie mogłaby rzutować na jego szybkość, dotyczy brzmienia art. 470 k.p.c., według którego pozwany ma obowiązek zapewnić, by osoba reprezentująca go przy czynnościach sądu była obeznana ze stanem faktycznym sprawy i umocowana do zawarcia ugody. Zmiana przepisu związana była z uchyleniem przepisu o czynnościach wyjaśniających. Wskazuje się, iż zastąpienie dotychczasowego określenia „strona pozwana” terminem „pozwany”, a pojęcia osoby „uprawnionej” słowem „umocowanej” w zasadzie nie zmieniło istoty dotychczasowej regulacji. Nie jest także jasne, na czym ma polegać obowiązek „zapewnienia”, aby osoba reprezentująca pozwanego przy czynnościach sądu była obeznana ze stanem faktycznym sprawy i umocowana do zawarcia ugody ${ }^{39}$. Co więcej, w moim odczuciu poprzedni obowiązek ,powinności” reprezentacji był bardziej stanowczy, co również bardziej mogło rzutować na przyspieszenie rozpoznania sprawy.

\section{RYGOR PRZYWRÓCENIA DO PRACY}

Największe kontrowersje stwarza znowelizowany art. $477^{2}$ k.p.c., który na wniosek pracownika przewiduje możliwość nałożenia przez sąd w wyroku na pracodawcę obowiązku dalszego zatrudnienia pracownika do czasu prawomocnego zakończenia postępowania. Do tej pory obowiązek taki mógł zostać nałożony tylko w wypadku roszczenia o uznanie wypowiedzenia umowy o pracę za bezskuteczne. W uzasadnieniu ustawy nowelizującej podaje się, iż „doświadczenia praktyki wskazują, że niemal żaden proces o uznanie wypowiedzenia umowy o pracę za bezskuteczne nie kończy się w terminie umożliwiającym zastosowanie instytucji z art. $477^{2} \S 2$. Aby nadać tej instytucji realne znaczenie, należy przesłanki

36 Zob. art. $477^{7}$ k.p.c.

37 Zob. art. $475^{1}$ k.p.c.

38 Zob. art. $424^{12}$ k.p.c.

39 I. Gil, komentarz do art. 470 k.p.c, teza 5, [w:] Kodeks postepowania cywilnego. Komentarz, red. E. Marszałkowska-Krześ, Warszawa 2020. Zob. art. 470 k.p.c. w poprzednim brzmieniu: „W razie podjęcia czynności wyjaśniających lub zarządzenia osobistego stawiennictwa na rozprawę, strona pozwana powinna być reprezentowana przez osobę obeznaną ze stanem faktycznym sprawy i uprawnioną do zawarcia ugody". 
jej zastosowania poszerzyć o przywrócenie pracownika do pracy"40. Dlatego też moim zdaniem przepis ten należy postrzegać jako instytucję mającą na celu przyśpieszenie postępowania $\mathrm{w}$ sprawach $\mathrm{z}$ zakresu prawa pracy, a przynajmniej przyśpieszenie zaspokojenia istotnych z życiowego punktu widzenia roszczeń pracownika. Powrót do pracy po ponad rocznym procesie (zakładając jego pozytywny wynik) z reguły bowiem $\mathrm{z}$ wielu powodów zawodowych i społecznych nie jest satysfakcjonujący. Odległy wynik sprawy rzutować może także w praktyce na wybór ostatecznie przez pracownika słabszego roszczenia odszkodowawczego zamiast przywrócenia do pracy.

Na mocy nowelizacji do cytowanego przepisu zmieniony został $\S 2^{41}$ art. 477 k.p.c., zgodnie z którym, uznając wypowiedzenie umowy o pracę za bezskuteczne albo przywracając pracownika do pracy, sąd na wniosek pracownika może w wyroku nałożyć na pracodawcę obowiązek dalszego zatrudnienia pracownika do czasu prawomocnego zakończenia postępowania. Jest to instytucja bardzo ważna z socjalnego punktu widzenia, albowiem pozwala pracownikowi na kontynuację pracy za wynagrodzeniem, przez co nie pozostaje bez środków do życia i nie traci więzi społecznych oraz zawodowych z zakładem pracy. Jest to tym bardziej znaczące, albowiem po przywróceniu do pracy po wieloletnim procesie pracownik (z wyjątkiem pracowników szczególnie chronionych) może otrzymać jedynie wynagrodzenie za okres od jednego do trzech miesięcy (art. 47, 57 § 1 k.p.). Nowo dodany przepis $\mathrm{w}$ zamierzeniu spełnia nie tyle funkcję ochronną, ile niewątpliwie socjalną. Może także w sprawach związanych z bytem stosunku pracy istotnie przyczynić się do przyśpieszenia tego rodzaju postępowań.

W doktrynie nałożenie omawianego obowiązku nazywa się tymczasowym przywróceniem do pracy ${ }^{42}$. Celem przepisu jest możliwość przywrócenia pracownika do pracy na podstawie nieprawomocnego wyroku. Wniosek o przywrócenie do pracy może być złożony zarówno w pozwie, jak i w innym piśmie procesowym (lub ustnie do protokołu) do momentu zamknięcia postępowania w sprawie. Nie ma on charakteru roszczeniowego i podlega ocenie sądu rozpoznającego ${ }^{43}$. Przepis stanowi bowiem, iż sąd „może” wniosek uwzględnić, jednakże w literaturze słusznie moim zdaniem wskazuje się, że regułą powinno być nałożenie na praco-

40 Uzasadnienie rządowego projektu..., s. 114.

41 Przepis $\S 1$ art. $477^{2}$ k.p.c. pozostał w dotychczasowym brzmieniu: „Zasądzając należność pracownika w sprawach z zakresu prawa pracy, sąd z urzędu nada wyrokowi przy jego wydaniu rygor natychmiastowej wykonalności w części nieprzekraczającej pełnego jednomiesięcznego wynagrodzenia pracownika. Przepis art. $334 \S 4$ i art. $335 \S 1$ zdanie drugie stosuje się odpowiednio; nie stosuje się przepisu art. $335 \S 2$ ".

42 K. Jaśkowski, E. Maniewska, Tymczasowe przywrócenie pracownika do pracy (art. $477^{2}$ $\S 2$ k.p.c.), „Praca i Zabezpieczenie Społeczne” 2020, nr 9, s. 15 n.

43 K. Żywolewska, Obowiazek dalszego zatrudniania pracownika przywróconego do pracy do czasu prawomocnego zakończenia postępowania po nowelizacji art. $477^{2}$ \& 2 k.p.c. - wybrane problemy, „Praca i Zabezpieczenie Społeczne” 2020, nr 1, s. 31. 
dawcę obowiązku dalszego zatrudnienia pracownika ${ }^{44}$. W przypadku pracodawców będzie to niewątpliwie dodatkowy koszt, ale także przestroga przed podejmowaniem zbyt pochopnych decyzji zwolnieniowych. Oznaczać będzie obowiązek zatrudnienia wbrew woli pracodawcy. Z punktu widzenia pracodawców może okazać się to korzystne w stosunku do pracowników szczególnie chronionych, którym przysługuje wynagrodzenie za cały okres pracy ${ }^{45}$.

Przepis ten, mimo że wywołuje wiele kontrowersji w praktyce i prowokuje różne interpretacje doktryny, z punktu widzenia zasady szybkości postępowania zasługuje moim zdaniem na ocenę pozytywną. Dlatego też podzielam pogląd, iż nałożenie obowiązku dalszego zatrudnienia pracownika przez sąd pracy na pracodawcę realizuje postulat szybkości i efektywności działania wymiaru sprawiedliwości ${ }^{46}$.

Sporne pozostaje, czy instytucja ta dotyczy wypowiedzenia umowy o pracę, czy też rozwiązania bez wypowiedzenia ${ }^{47}$. Zgadzam się z poglądami, że dotyczy on również tego drugiego przypadku. E. Maniewska i K. Jaśkiewicz ze zwrotu „albo przywracając pracownika do pracy” wywodzą rozszerzenie tego przepisu także na rozwiązanie umowy o pracę bez wypowiedzenia ${ }^{48}$. Autorzy słusznie wskazują na te same przesłanki celowościowe ${ }^{49}$.

Według K. Żywolewskiej w celu wykonania wyroku nieprawomocnego odpowiednie zastosowanie ma art. $48 \S 1$ k.p., według którego pracodawca nie może odmówić ponownego zatrudnienia pracownika, jeżeli w ciągu siedmiu dni od przywrócenia do pracy nie zgłosił on gotowości niezwłocznego podjęcia pracy, chyba że przekroczenie terminu nastąpiło z przyczyn niezależnych ${ }^{50}$. W tym przypadku pracownik nie ma także problemów z ustaleniem prawomocności wyroku. Na marginesie wskazać bowiem należy, że wśród praktyków podkreśla się celowość wprowadzenia zmiany legislacyjnej nakładającej na sąd czy też pracodawcę obowiązek poinformowania pracownika o prawomocności orzeczenia przywracającego do pracy i utrzymaniu siedmiodniowego terminu na zgłoszenie przez pracownika gotowości podjęcia pracy od daty otrzymania powiadomienia ${ }^{51}$.

Na koniec trzeba wspomnieć, że w literaturze wskazano na niedostateczność znowelizowanego art. $477^{2} \S 2$ k.p. jako środka ochrony sygnalistów ${ }^{52}$. Jako przykłady innych krajów M. Kozak-Maśnicka podaje irlandzką (Protected Disclosures

44 K. Jaśkowski, E. Maniewska, op. cit., s. 17.

45 K. Żywolewska, op. cit., s. 26.

46 K. Jaśkowski, E. Maniewska, op. cit., s. 17.

47 Negatywne stanowisko w tej kwestii zajmuje K. Żywolewska, op. cit., s. 27, wraz z przytaczanymi tam poglądami doktryny.

48 K. Jaśkowski, E. Maniewska, op. cit., s. 16.

49 Ibidem; por. także J. May, op. cit., s. 45.

${ }^{50}$ K. Żywolewska, op. cit., s. 28.

51 L. Laska, Przywrócenie do pracy po wyroku sądowym, OPZZ, https://www.opzz.org.pl/ aktualnosci/kraj/przywrocenie-do-pracy-po-wyroku-sadowym (dostęp: 2.02.2021).

52 M. Kozak-Maśnicka, Dyrektywa w sprawie ochrony osób zgłaszających naruszenia prawa Unii jako wyzwanie dla polskiego ustawodawcy, „Monitor Prawa Pracy” 2020, nr 4, s. 17. 
Act 2014, dział 11) i brytyjską (Public Interest Disclosure Act, 1998, art. 9) ustawę przewidującą specjalny środek tymczasowy w postaci szczegółowej procedury przywrócenia do pracy na wniosek sygnalisty w trakcie postępowania sądowe$\mathrm{go}^{53}$. Dlatego też de lege ferenda warto w tym kontekście poszerzyć regulacje art. 477 k.p.c. również o szczególną sytuację sygnalistów.

\section{PODSUMOWANIE}

Reasumując, uważam, że wprowadzone zmiany w postępowaniu odrębnym w sprawach z zakresu prawa pracy mają charakter przede wszystkim formalny i raczej nie wpłyną na przyśpieszenie postępowania $\mathrm{w}$ tym obszarze $\mathrm{w}$ stopniu wyższym niż do tej pory. Zwrócić należy uwagę na liczne uwagi krytyczne co do samego postępowania przygotowawczego w sprawach pracowniczych.

Aktualnie na rozstrzygnięcie sprawy z zakresu prawa pracy oczekuje się niemal tak długo jak w innych sprawach cywilnych ${ }^{54}$. Z badań ankietowych P. Grzebyka ${ }^{55}$ wynika, że w $35,3 \%$ przypadków pierwszą rozprawę wyznaczono w okresie do trzech miesięcy od wniesienia pozwu. W 33,5\% spraw pierwsza rozprawa odbyła się w okresie od trzech miesięcy do pół roku. Aż 27,5\% spraw odnosi się do okresu od sześciu miesięcy do jednego roku. Gdy postępowanie toczy się w dwóch instancjach, większość rozstrzygnięć kończących postępowanie w sprawie zapada w okresie od jednego roku do dwóch lat od dnia wniesienia pozwu ${ }^{56}$.

Nowo wprowadzone przepisy w zakresie postępowania cywilnego w sprawach z zakresu prawa pracy nie napawają optymizmem w tym zakresie. Właściwie za jedyną znaczącą zmianę, która może wpływać na przyśpieszenie postępowań, należy uznać dodany $\S 2$ art. $477^{2}$ k.p.c. w zakresie możliwości tymczasowego przywrócenia do pracy pracownika. Nie wiadomo jednak, jak często sądy będą w praktyce wykorzystywały tę instytucję.

53 Ibidem, s. 17.

54 A. Góra-Błaszczykowska, [w:] System Prawa Pracy, t. 6. Procesowe prawo pracy, Warszawa 2016, s. 411.

55 P. Grzebyk, Analiza orzecznictwa sądowego w sprawach o ustalenie istnienia stosunku pracy. Zatrudnienie pracownicze a zatrudnienie cywilnoprawne, Warszawa 2015, https://iws.gov. pl/wp-content/uploads/2019/03/IWS_Grzebyk-P._Ustalenie-istnienia-stosunku-pracy.pdf, s. 60 (dostęp: 5.01.2021).

56 Ibidem. 


\title{
THE PRINCIPLE OF SPEED OF PROCEEDINGS IN THE LABOUR LAW MATTERS AFTER THE AMENDMENT OF THE CODE OF CIVIL PROCEDURE
}

\author{
Summary
}

The subject of this article is an analysis of the most important regulations of civil procedure in the labour law matters introduced under the amendment in 2019 in relation to the principle of speed of proceedings formulated in doctrine.

The author analyses the foundations of this principle in national and international law.

Then the author analyses the general new model of civil procedure and the main changes to law in the separate proceedings in the labour law matters from the perspective of this procedural principle.

Keywords: civil procedure, labour law matters, the principle of speed of proceedings, employee, plaintiff

\section{BIBLIOGRAFIA}

Baran K.W., [w:] Prawo pracy i ubezpieczeń społecznych, red. K.W. Baran, Warszawa 2019.

Dziurda M., Posiedzenie przygotowawcze i plan rozprawy, [w:] Reforma czy kolejna nowelizacja? Uwagi na tle ustawy z 4.7.2019 r. zmieniajacej KPC, red. P. Rylski, Warszawa 2020.

Flaga-Gieruszyńska K., Czynności wyjaśniające, [w:] System Prawa Pracy, t. 6. Procesowe prawo pracy, red. K.W. Baran, Warszawa 2016.

Flejszar R., Postepowania przyspieszone po zmianach wprowadzonych nowelizacja KPC z 4.7.2019 r., „Monitor Prawniczy” 2019, nr 21.

Gil I., komentarz do art. 470 k.p.c., [w:] Kodeks postepowania cywilnego. Komentarz, red. E. Marszałkowska-Krześ, Warszawa 2020.

Gonera K., komentarz do art. 471 k.p.c., [w:] Kodeks postępowania cywilnego, t. 3. Komentarz. Art. 425-729, red. A. Marciniak, Warszawa 2020.

Góra-Błaszczykowska A., [w:] System Prawa Pracy, t. 6. Procesowe prawo pracy, red. K.W. Baran, Warszawa 2016.

Grzebyk P., Analiza orzecznictwa sądowego w sprawach o ustalenie istnienia stosunku pracy. Zatrudnienie pracownicze a zatrudnienie cywilnoprawne, Warszawa 2015, https://iws.gov.pl/ wp-content/uploads/2019/03/IWS_Grzebyk-P._Ustalenie-istnienia-stosunku-pracy.pdf (dostęp: 5.01.2021).

Grzegorczyk P., Weitz K., komentarz do art. 45 Konstytucji RP, [w:] Konstytucja RP, t. 1. Komentarz do art. 1-86, red. M. Safjan, L. Bosek, Warszawa 2016.

Jaśkowski K., Maniewska E., Tymczasowe przywrócenie pracownika do pracy (art. $477^{2}$ \& 2 k.p.c.), „Praca i Zabezpieczenie Społeczne” 2020, nr 9.

Kozak-Maśnicka M., Dyrektywa w sprawie ochrony osób zgłaszajacych naruszenia prawa Unii jako wyzwanie dla polskiego ustawodawcy, „Monitor Prawa Pracy” 2020, $\mathrm{nr} 4$.

Laska L., Przywrócenie do pracy po wyroku sądowym, OPZZ, https://www.opzz.org.pl/aktualnosci/ kraj/przywrocenie-do-pracy-po-wyroku-sadowym (dostęp: 2.02.2021).

Liszcz T., Prawo pracy, Warszawa 2014.

May J., Proceedings in matters of labour law after the amendment to the Polish Code of Civil Procedure, „Praca i Zabezpieczenie Społeczne” 2020, nr 3. 
Mendrek A., Reforma prawa dowodowego w świetle ustawy z 4.07.2019 r. o zmianie ustawy Kodeks postępowania cywilnego oraz niektórych innych ustaw, [w:] Nowelizacja Kodeksu postępowania cywilnego z 4.07.2019 r. w praktyce, red. K. Flaga-Gieruszyńska, R. Flejszar, M. Malczyk, Warszawa 2020.

Mędrala M., Funkcja ochronna cywilnego postępowania sądowego w sprawach z zakresu prawa pracy, Warszawa 2011.

Muliński M., komentarz do art. 467 k.p.c., [w:] Kodeks postępowania cywilnego, t. 1. B. Komentarz. Art. 425-729, red. A. Góra-Błaszczykowska, Warszawa 2020.

Półtorak N., Wróbel A., komentarz do artykułu 47 Karty Praw Podstawowych, [w:] Karta Praw Podstawowych Unii Europejskiej. Komentarz, red. A. Wróbel, Legalis 2020.

Sieńko M., Nowe modele koncentracji materiatu procesowego, [w:] Reforma czy kolejna nowelizacja? Uwagi na tle ustawy z 4.7.2019 r. zmieniajacej KPC, red. P. Rylski, Warszawa 2020.

Ślebzak K., [w:] Prawo pracy, red. Z. Niedbała, Warszawa 2012.

Świeboda Z., [w:] W. Siedlecki, Z. Świeboda, Postępowanie cywilne. Zarys wykładu, Warszawa 2004.

Żywolewska K., Obowiązek dalszego zatrudniania pracownika przywróconego do pracy do czasu prawomocnego zakończenia postępowania po nowelizacji art. $477^{2} \xi 2$ k.p.c. - wybrane problemy, „Praca i Zabezpieczenie Społeczne” 2020, nr 1. 